\title{
Knowledge Assessment on Female Genital Mutilation (FGM) in Tulli and Ararso Districts, Somali Regional State, Ethiopia
}

\section{Reta Wakoya Anbesse*, Eshetu Gadisa and Getachew Ebissa}

Kotebe Metropolitan University, Menelik II Medical and Health Science College, Biomedical Science, Ethiopia

*Corresponding Author: Reta Wakoya Anbesse, Kotebe Metropolitan University, Menelik II Medical and Health Science College, Biomedical Science, Ethiopia.

DOI: $10.31080 /$ ASWH.2020.02.0091
Received: January 17, 2020

Published: February 10, 2020

(C) All rights are reserved by Reta Wakoya

Anbesse., et al.

\begin{abstract}
Background: The livelihoods of most the Somali regional state people are based on herding and their life styles are mobile. The harmful traditional practices particularly female genital mutilation seriously affects the well-being of children and women. The age at which FGM is performed varies according to the type of mutilation being done. Sunna is generally the type that is performed at a very young age and even soon after the birth. In case of excision and infibulations, the child is allowed to grow older and usually performed between seven and nine years of age. This study aimed to assess the current actual status of female genital mutilation in the Tulli and Ararso districts.

Methods: A total of 57 subjects were included for quantitative and qualitative analysis. In the two sites about 15 Men and Women, 9 Youth clubs, 5 Victims, 7 boys, 4 Circumcisers, 6 religious leaders or elders, 6 local governments, and 5 Women's Associations were interviewed. Under the quantitative approach, a structured questionnaire was prepared and piloted and administered through interview of individuals that were included in the sample.

Result: Interview of men and women revealed that $53.7 \%$ of females were circumcised at Tulli and Ararso Somali areas. Interview of youth club also showed that $40 \%$ of the circumcision practices were continued and culture of ancestors and protection of virginity were still the two common reasons for circumcision practices in the locality. In all respondents interviewed, Sunna is the most commonly practiced type of FGM and Pharaohnic is the second type.

Conclusion: Convincing discussions and focused training need to be given to men and women, youth clubs, victims, boys, circumcisers, religious leaders, local governments and women's Association to eradicate the FGM practice in the areas since knowledge, attitude and behaviors of the individuals with regard to FGM are still mixed.

Keywords: Female Genital Mutilations; Harmful Traditional Practices; Circumcision; Cultural; Religious
\end{abstract}

\section{Abbreviations}

BCC: Behavioral Change Communication; FGM: Female Genital Mutilation; FGD: Focus Group Discussion; HIV: Human Immunodeficiency Virus; HTTP: Harmful Traditional Practices; IEC: Information Education and Communication; IGA: Income Generating Activities; KAP: Knowledge, Attitudes, and Practices; MCDO: Mother and Child Development Organization; TBA: Traditional Birth Attendants; TTBA: Trained Traditional Birth Attendants; WHO: World Health Organization.

\section{Introduction}

The Somali Regional State (SRS) is located in the Eastern part of Ethiopia, bordering the Republic of Somalia in the Southeast, Oromia in the East and South and Affair in the West. The livelihoods of most Somali people are based mainly on herding, while their life styles are nomadic mobile. They moved from place to place in search of grass and water for their animals, particularly people in Ararso. And some Somali people are agro-pastoral especially in Tulli. The economic condition of Somali region was relatively lower than other regions of Ethiopia because the region was not given enough attention for development during the previous periods while recurrent drought has obliged the people to lead a life of internal displacement.

The harmful traditional practices (HTP) particularly female genital mutilation seriously affects the well-being of children and women. FGM is a traditional operation that involves cutting away parts of the female external genitalia or other injuries to the female genitalia for cultural reasons [1]. It reflects deep-rooted inequality between the sexes, and constitutes an extreme form of discrimination against women. The practice is mostly carried out by traditional circumcisers, who often play other central roles in communities, such as attending childbirths [2]. The World Health Organization (WHO) estimate that 100 - 140 million girls and women currently 
live with the consequences of FGM and that at least three million girls and women undergo some form of the procedure every year. Most of these girls and women live in 28 African countries, mainly in west, east and north-east Africa [3]. According to the definition of the WHO, Female genital mutilation comprises all procedures involving partial or total removal of the external female genitalia or other injury to the female genital organs whether for cultural, religious or other non-therapeutic reasons and does not include medically prescribed surgery or that which is performed for sex change reasons [4].

Female circumcision is a universal practice that results in many health-related and life-threatening complications. It also has other physical and psychological effects that do great harm to the wellbeing of women and children who have had it performed on them. FGM is practiced at all educational levels and in all social classes and occurs among many religious groups (Muslims, Christians, and animists), although no religion mandates it (5).Procedures vary throughout the world but the WHO classifies FGM into four types as follows [4];

- Type 1: Excision of the prepuce with or without excision of the clitoris.

- Type 2: Excision of the clitoris with partial or total excision of the labia minor

- Type 3: Excision of part or all of the external genitalia and stitching together of the exposed walls of the labia majora, leaving only a small hole (typically less than $5 \mathrm{~cm}$ ) to permit the passage of urine and vaginal secretions. This hole may need extending at the time of the menarche and often before first intercourse.

- Type 4: Unclassified, covers any other damage to the female genitalia including pricking, piercing, burning, cutting or introduction of corrosive substances.

The day of the FGM is considered an important event but it is kept secret from the pre-menarche child, and then sprung upon her once the necessary preparations have been made. Senior female members of the community, relatives, traditional birth attendants (TBAs) or occasionally healthcare workers may be called upon to carry out the procedure [4]. The practice itself often takes place in remote rural areas by untrained village midwives who use instruments such as knives, razors or even broken glass. The instruments are often not sterile and the ritual is very often performed in unsanitary condition [6].

The age at which female genital mutilation is performed varies from country to country and according to the type of mutilation being done. The Sunna is generally the type that is performed at a very young age and may be carried out soon after birth, during the first week of life or at any time before the Menarche [4]. In the case of Excicion and Infibulation, when more tissues are to be removed which entail more manipulations, the child is allowed to grow older so that the tissues intended for excision are also given a chance to grow. This gives the operator a better pinch or grip. According to the findings of our survey, it was found that the usual age when excision and infibulations are performed is between seven and nine years of age [4].

Beyond the obvious initial pain of the procedure, the long-term physiological, sexual and psychological effects of FGM are well [5] documented. The consequences can even include death as a result of shock, hemorrhage or septicemia. Long-term complications include loss of libido, genital malformation, delayed menarche chronic pelvic complications and recurrent urinary retention and infection [7]. FGM victims are also prone to a number of obstetric complications because the fetus is exposed to a range of infectious diseases and faces the risk of having its head crushed in the damaged birth canal. Infibulated women, whose genitals have been tightly closed, have to be cut open to allow the baby to emerge. Perineal tears, obstructed labour and fistula can occur. The repeated cutting and re-stitching of a woman's genitals with each birth can result in tough scar tissue. In addition to direct adverse health effects, FGM increases the woman's biological vulnerability to HIV transmission if exposed to the virus [6].

The historical roots of the practice are not well-known but they appear to date back 2,000 years to ancient Egypt during the time of the Pharaohs. A global review of FGM shows that the custom of FGM is known to be practiced in one form or another in more than 28 countries in Africa including Ethiopia. It also says $60 \%$ of Ethiopian woman support the practice. In places where FGM takes place it is performed during infancy, childhood or adolescence [1]. In Somalia, FGM prevalence is about 95 percent and is primarily performed on girls aged 4-11. FGM can have severely adverse effects on the physical, mental and psychosocial wellbeing of those who undergo the practice. The health consequences of FGM are both immediate and life-long [6].

The worst type of FGM, infibulations, is performed in Somali region. The process for infibulations (Type III) entails that narrowing of the vaginal opening through the creation of a covering seal. The seal is formed by cutting and repositioning the inner, or outer, labia, with or without removal of the clitoris. Then the bleeding sides of the labia majora are sewn up with silk, catgut or held together with thorns inserted horizontally [8]. If the girl survives and the wound has healed, the entrance to the vagina is closed except for a tiny opening created by inserting a splinter of wood. Though the reasons for practicing FGM vary from society to society, the following are commonly mentioned as a reason for undergoing FGM: to maintain the moral behavior of women in the society, to preserve 
virginity, for hygienic reasons, to 'calm' a girl and make her decent, esthetic reasons, religious requirement, to avoid difficulty at delivery. i.e. Some people believe that FGM helps to shorten the duration of labor and the passage of the newborn child through the birth canal, despite evidence to the contrary), to increase matrimonial and marriage opportunities [1].

\section{Methods}

Sampling methods

This study was conducted in two specific areas called Tulli and Ararso of Somali region. Under the quantitative approach, information was collected from the general public to generate information on KAPB on FGM. Assuming the study is mainly qualitative, convenience sampling was made and a total of 57 subjects were included for quantitative and qualitative analysis. In the two sites about 15 Men and Women, 9 Youth clubs, 5 Victims, 7 boys, 4 Circumcisers, 6 religious leaders or elders, 6 local governments, and 5 Women's Associations were interviewed.

\section{Data collection instruments}

The data collection instrument (structured/semi-structured questionnaire and open-ended questions) was prepared to collect information from the selected individuals and key informants. The questionnaire that was used to collect the quantitative information from individuals was structured as much as possible and was designed to collect information from men and women, youths, victims and boys.

The key informant semi-structured questionnaire had general questions on address; background characteristics; knowledge, attitudes and practices on FGM; and the rest were open-ended questions to answer most of the specific objectives of this assessment.

\section{Interviewer guide}

After finalizing the data collection instrument, interview guide was prepared for the questionnaires. The guide was clearly prepared on how to complete the questionnaire, on the selection of the samples and on the process of recording after interview. In a similar manner a guideline was also be prepared for in-depth interview.

\section{Data entry, analysis}

After appropriate final editing and coding, the collected data was entered into a computer using the SPSS 20 software. Descriptive frequency analyses were performed to generate the information that can answer the general and specific objectives of this assessment. During the analysis, all desegregation or stratification was performed by site, sex, age, education and other relevant variables.

\section{Results}

Result of the quantitative information

Table 1 presents frequency distribution of women and men respondents by background characteristics on FGM at Tulli and Ararso. Accordingly, from a total of 54 females identified by men and women respondents, 29 (53.7\%) were circumcised while only 25 (46.3\%) of females were left uncircumcised in Tulli and Ararso. Majority of families had 1 - 4 male (86.7\%) and 1 - 4 female (53.3\%) children; and $60 \%$ of the men and women agreed not to circumcise their non-circumcised daughters. Sunna (73.3\%) was the most widely employed circumcision type and Pharaohnic (26.7\%) was the second circumcision type practiced in the areas. Culture of ancestors (66.6\%) and religious requirements $(26.7 \%)$ were the first and second leading causes of circumcision while mothers were top in insisting on the need of female genital mutilation (FGM) in the areas. Additionally, the circumcision processes in the areas were undertaken mostly with payment for circumcisers (80\%) and the average amount of Birr paid was approximately 149 Ethiopian Birr. Furthermore, majority of the men and women (60\%) had knowledge about the health consequences of circumcision and most of them (73.3\%) agree to having their sons married with uncircumcised girls marry their son from a girl who was not circumcised.

\begin{tabular}{|c|c|c|c|}
\hline Variable & $\begin{array}{c}\text { Frequen- } \\
\text { cy }\end{array}$ & $\begin{array}{c}\text { Percent } \\
(\%)\end{array}$ & Mean \\
\hline \multicolumn{4}{|l|}{ Men and women's specific area $(\mathrm{N}=15)$} \\
\hline Tulli & 9 & 60 & \\
\hline Ararso & 6 & 40 & \\
\hline \multicolumn{4}{|l|}{$\begin{array}{l}\text { Number of children men and women } \\
\text { had }(\mathrm{N}=102)\end{array}$} \\
\hline Male & 48 & 47 & \\
\hline Female & 54 & 53 & \\
\hline \multicolumn{4}{|l|}{$\begin{array}{l}\text { Number of children of men and women } \\
\text { respondents stratified by size }\end{array}$} \\
\hline 2 - 4 children & 2 & 13.3 & \\
\hline 5 - 8 children & 9 & 60 & \\
\hline 9 - 12 children & 4 & 26.7 & \\
\hline \multicolumn{4}{|l|}{$\begin{array}{l}\text { Number of male children of men and } \\
\text { women respondents stratified by size }\end{array}$} \\
\hline 1 - 4 male children & 13 & 86.7 & \\
\hline 5 - 10 male children & 2 & 13.3 & \\
\hline \multicolumn{4}{|l|}{$\begin{array}{l}\text { Number of female children of men and } \\
\text { women respondents stratified by size }\end{array}$} \\
\hline 1 - 4 females & 8 & 53.3 & \\
\hline 5 - 8 females & 7 & 46.7 & \\
\hline \multicolumn{4}{|l|}{$\begin{array}{l}\text { Circumcision Status of the females } \\
\text { identified }\end{array}$} \\
\hline Circumcised & 29 & 53.7 & \\
\hline
\end{tabular}




\begin{tabular}{|c|c|c|c|}
\hline Not circumcised & 25 & 46.3 & \\
\hline \multicolumn{4}{|l|}{$\begin{array}{l}\text { Willingness of men and women } \\
\text { respondents to circumcise their non- } \\
\text { circumcised daughters }\end{array}$} \\
\hline Yes & 6 & 40 & \\
\hline No & 9 & 60 & \\
\hline \multicolumn{4}{|l|}{$\begin{array}{l}\text { Type of circumcision practiced in the } \\
\text { areas identified by men and women } \\
\text { respondents }\end{array}$} \\
\hline Sunna & 11 & 73.3 & \\
\hline Pharaohnic & 4 & 26.7 & \\
\hline \multicolumn{4}{|l|}{$\begin{array}{l}\text { Reason for circumcision of daughters } \\
\text { identified by men and women respon- } \\
\text { dents }\end{array}$} \\
\hline Religious requirement & 4 & 26.7 & \\
\hline Peer pressure & 1 & 6.7 & \\
\hline Culture of ancestors & 10 & 66.6 & \\
\hline \multicolumn{4}{|l|}{$\begin{array}{l}\text { Insister on the need of FGM identified } \\
\text { by men and women respondents }\end{array}$} \\
\hline Sisters & 1 & 6.7 & \\
\hline Mothers & 13 & 86.6 & \\
\hline Brothers & 1 & 6.7 & \\
\hline \multicolumn{4}{|l|}{$\begin{array}{l}\text { Payment status for circumcisers identi- } \\
\text { fied by men and women respondents }\end{array}$} \\
\hline Yes & 12 & 80 & \\
\hline No & 3 & 20 & \\
\hline $\begin{array}{l}\text { Average amount of payment for cir- } \\
\text { cumcisers (Ethiopian Birr) }\end{array}$ & & & 149.3 \\
\hline \multicolumn{4}{|l|}{$\begin{array}{l}\text { Awareness of men and women respon- } \\
\text { dents on the presence of non-circum- } \\
\text { cised women in the areas }\end{array}$} \\
\hline Yes & 8 & 53.3 & \\
\hline No & 6 & 40 & \\
\hline No data & 1 & 6.7 & \\
\hline \multicolumn{4}{|l|}{$\begin{array}{l}\text { Knowledge status of men and women } \\
\text { respondents about problems faced by } \\
\text { non-circumcised women }\end{array}$} \\
\hline Yes & 6 & 40 & \\
\hline No & 9 & 60 & \\
\hline \multicolumn{4}{|l|}{$\begin{array}{l}\text { Attitude of men and women respon- } \\
\text { dents towards marriage status of their } \\
\text { son with non-circumcised girl }\end{array}$} \\
\hline Yes & 11 & 73.3 & \\
\hline No & 4 & 27.3 & \\
\hline \multicolumn{4}{|l|}{$\begin{array}{l}\text { Knowledge status of men and women } \\
\text { respondents on consequences of FGM }\end{array}$} \\
\hline Yes & 9 & 60 & \\
\hline No & 6 & 40 & \\
\hline
\end{tabular}

Table 1: Frequency distribution of women and men respondents about FGM at Tulli and Ararso, Somali, Ethiopia.
Result of the qualitative information

Table 2 presents frequency distribution of youth club respondents by background characteristics, knowledge, attitude, and practices on FGM at Tulli and Ararso. Accordingly, from the 9 youth club, $8(88.9 \%)$ of them were male and $6(66.7 \%)$ of them had

\begin{tabular}{|c|c|c|c|}
\hline Variable & Frequency & Percent(\%) & Mean \\
\hline \multicolumn{4}{|l|}{ Area } \\
\hline Tulli & 5 & 55.6 & \\
\hline Ararso & 4 & 44.4 & \\
\hline \multicolumn{4}{|l|}{ Sex of respondents } \\
\hline Male & 8 & 88.9 & \\
\hline Female & 1 & 11.1 & \\
\hline \multicolumn{4}{|l|}{ Age of respondents } \\
\hline $12-18$ & 3 & 33.3 & \\
\hline $19-23$ & 6 & 66.7 & \\
\hline \multicolumn{4}{|l|}{ Educational level of youths } \\
\hline 5 - 8 grades & 2 & 22.2 & \\
\hline $9-12$ grades & 3 & 33.3 & \\
\hline Above grade 12 & 4 & 44.5 & \\
\hline \multicolumn{4}{|l|}{$\begin{array}{l}\text { Number of brothers and } \\
\text { sisters of youths }(\mathrm{N}=33)\end{array}$} \\
\hline Number of sisters & 15 & 45.5 & \\
\hline Number of brothers & 18 & 54.5 & \\
\hline \multicolumn{4}{|l|}{$\begin{array}{l}\text { Circumcision status of } \\
\text { youth's sisters }\end{array}$} \\
\hline Circumcised & 9 & 60 & \\
\hline Not circumcised & 6 & 40 & \\
\hline \multicolumn{4}{|l|}{$\begin{array}{l}\text { Reason of circumcision } \\
\text { identified by youth }\end{array}$} \\
\hline Protection of virginity & 3 & 33.3 & \\
\hline Culture of ancestors & 6 & 66.7 & \\
\hline \multicolumn{4}{|l|}{$\begin{array}{l}\text { Places where FGMs are } \\
\text { commonly done identified } \\
\text { by youth }\end{array}$} \\
\hline In the house & 8 & 88.9 & \\
\hline Outside the village & 1 & 11.1 & \\
\hline \multicolumn{4}{|l|}{$\begin{array}{l}\text { Knowledge status of youth } \\
\text { on health problems faced } \\
\text { after circumcision }\end{array}$} \\
\hline Knowledgeable & 6 & 60 & \\
\hline Not knowledgeable & 3 & 40 & \\
\hline $\begin{array}{l}\text { Average amount of birr } \\
\text { paid for circumcisers }\end{array}$ & & & 210 \\
\hline \multicolumn{4}{|l|}{$\begin{array}{l}\text { Intention of youths to stop } \\
\text { FGM }\end{array}$} \\
\hline Agree to stop & 8 & 88.9 & \\
\hline Do not agree & 1 & 11.1 & \\
\hline
\end{tabular}

Table 2: Frequency distribution of youth club respondents about FGM at Tulli and Ararso, Somali, Ethiopia. 
an age range of 19 - 23 years. Majority of the youths were educated above grade 12 (44.5\%). The total number of sisters that the youths interviewed had was 15 from which only $6(40 \%)$ of females were left not circumcised. The youths club discussed that culture of ancestors $(66.7 \%)$ and protection of virginity $(33.3 \%)$ were the two common reasons for circumcision practices in the locality. Additionally, according to the youth club's explanation, majority (88.9\%) of FGM practices were done in the house and greater proportion $(60 \%)$ of the youth club member was knowledgeable about the health consequences resulted after FGM. Furthermore, the youth club felt that the average amount of birr paid for circumcisers per each circumcision was about 210 Ethiopian Birr and the club was in agreement with culmination of FGM practices in the areas.

Table 3 presents frequency distribution of victim respondents by knowledge, attitude, and practices on FGM at Tulli and Ararso. Accordingly, 5 individual victims were interviewed and all (100\%) of them felt health impacts of circumcision while only 3 (60\%) of them regretted for being circumcised. Moreover, most of the victims (80\%) did not get skill training or income generating activities (IGA) and they had a mixed interest to share their experience on FGM to others.

\begin{tabular}{|l|c|c|}
\hline \multicolumn{1}{|c|}{ Variable } & Frequency & Percent (\%) \\
\hline $\begin{array}{l}\text { Victim experienced problems after } \\
\text { circumcision (N=5) }\end{array}$ & & \\
\hline Yes & 5 & 100 \\
\hline No & 0 & 0 \\
\hline $\begin{array}{l}\text { Intention of victim for being } \\
\text { circumcised }\end{array}$ & 3 & 60 \\
\hline Regrets & 2 & 40 \\
\hline Do not regret & 1 & \\
\hline $\begin{array}{l}\text { Victim got skill training or IGA sup- } \\
\text { port }\end{array}$ & 4 & 80 \\
\hline Trained & & \\
\hline Not trained & 2 & 40 \\
\hline $\begin{array}{l}\text { Interest of victim to share her } \\
\text { experience about FGM to others }\end{array}$ & 2 & 20 \\
\hline Interested & & 40 \\
\hline Not interested & & \\
\hline No response &
\end{tabular}

Table 3: Frequency distribution of victim (girl) respondents about FGM at Tulli and Ararso, Somali, Ethiopia.

Table 4 presents frequency distribution of boy respondents by knowledge, attitude, and practices on FGM at Tulli and Ararso. Accordingly, 7 boys were interviewed and all (100\%) of them agreed that their sisters should not be circumcised and they all (100\%) were not interested to marry a girl who was circumcised. In addition, most of the boys (71.4\%) felt to advice others marry girls who were not circumcised.

\begin{tabular}{|l|c|c|}
\hline \multicolumn{1}{|c|}{ Variable } & Frequency & Percent (\%) \\
\hline $\begin{array}{l}\text { Attitude of boys towards circumcision } \\
\text { of their sisters (N=7) }\end{array}$ & & \\
\hline Agree & 0 & 0 \\
\hline Do not agree & 7 & 100 \\
\hline $\begin{array}{l}\text { Attitude of boys to marry circumcised } \\
\text { girl }\end{array}$ & & \\
\hline Agree & 0 & 0 \\
\hline Do not agree & 7 & 100 \\
\hline $\begin{array}{l}\text { Interest of boys to marry } \\
\text { uncircumcised girl }\end{array}$ & & \\
\hline Interested & 6 & 85.7 \\
\hline No response & 1 & 14.3 \\
\hline $\begin{array}{l}\text { Inclination of boys to advice others } \\
\text { marry un circumcised girl }\end{array}$ & & \\
\hline Inclined & 5 & 71.4 \\
\hline No response & 2 & 28.2 \\
\hline
\end{tabular}

Table 4: Frequency distribution of boy respondents about FGM at Tulli and Ararso, Somali, Ethiopia.

Table 5 presents frequency distribution of circumciser respondents by background characteristics, knowledge, attitude, and practices on FGM at Tulli and Ararso. Accordingly, 4 Circumcisers were interviewed and all (100\%) of them were married and Muslim in their religious affiliation. In majority of the cases (50\%), traditional birth attendants (TBA) and circumcision were the two common sources of money for the circumcisers and the average amount of money paid for circumcisers per each circumcision was approximately 175 Ethiopian Birr. In addition, about three-fourth (75\%) of circumcisers were knowledgeable on ill-health impacts of circumcision during delivery and others, however, most of them (75\%) were happy with the practices. In addition, half (50\%) of the circumcisers faced problems in the process of circumcision but $50 \%$ of them were not willing to stop FGM. Moreover, majority (75\%) of circumcisers were not trained on FGM and about $50 \%$ of them agreed on the continuity of the practice.

Table 6 presents frequency distribution of religious leader respondents by background characteristics, knowledge, attitude, and practices on FGM at Tulli and Ararso. Accordingly, 6 religious leaders were interviewed and all $(100 \%)$ of them had daughters and they felt that $50 \%$ of community members relate FGM to religion. Most daughters of the religious leaders (66.7\%) were not circumcised and majority of the religious leaders (83.3\%) explained that they had discussed with circumcisers to stop FGM. In addition, greater proportions $(66.6 \%)$ of the religious leaders were trained on circumcision practices and they mainly (83.3\%) felt to work with Women's Association. 


\begin{tabular}{|c|c|c|c|}
\hline Variable & Frequency & Percent & Mean \\
\hline \multicolumn{4}{|l|}{ Area } \\
\hline Tulli & 2 & 50 & \\
\hline Ararso & 2 & 50 & \\
\hline \multicolumn{4}{|l|}{ Age of circumciser } \\
\hline $25-45$ & 2 & 50 & \\
\hline $46-65$ & 2 & 50 & \\
\hline \multicolumn{4}{|l|}{ Marital status of circumciser } \\
\hline Single & 0 & 0 & \\
\hline Married & 4 & 100 & \\
\hline Widowed/separated/divorced & 0 & 0 & \\
\hline \multicolumn{4}{|l|}{ Religion of circumciser } \\
\hline Muslim & 4 & 100 & \\
\hline Christian or others & 0 & 0 & \\
\hline \multicolumn{4}{|l|}{ Source of Birr for survival } \\
\hline TBA & 1 & 25 & \\
\hline Circumciser & 1 & 25 & \\
\hline TBA and Circumciser & 2 & 50 & \\
\hline $\begin{array}{l}\text { Average amount of birr each } \\
\text { circumciser is paid per each } \\
\text { circumcision }\end{array}$ & & & 175.00 \\
\hline $\begin{array}{l}\text { Average number of girls } \\
\text { circumcised by each circumciser } \\
\text { per year }\end{array}$ & & & 25 \\
\hline \multicolumn{4}{|l|}{$\begin{array}{l}\text { Knowledge of circumciser on ill- } \\
\text { health effects of FGM }\end{array}$} \\
\hline Knowledgeable & 3 & 75 & \\
\hline Not Knowledgeable & 1 & 25 & \\
\hline \multicolumn{4}{|l|}{$\begin{array}{l}\text { Instruments used for FGM } \\
\text { identified by circumcisers }\end{array}$} \\
\hline Blade & 1 & 25 & \\
\hline Knife or scissor & 2 & 50 & \\
\hline Scissor or Knife & 1 & 25 & \\
\hline \multicolumn{4}{|l|}{$\begin{array}{l}\text { Feeling of circumciser about } \\
\text { circumcision }\end{array}$} \\
\hline Happy with it & 3 & 75 & \\
\hline Not happy with it & 1 & 25 & \\
\hline \multicolumn{4}{|l|}{$\begin{array}{l}\text { Circumciser had faced problem } \\
\text { in the process of FGM? }\end{array}$} \\
\hline Yes & 2 & 50 & \\
\hline No & 2 & 50 & \\
\hline $\begin{array}{l}\text { Suggestion of respondents to } \\
\text { stop FGM }\end{array}$ & 3 & 75 & \\
\hline \multicolumn{4}{|l|}{ Yes } \\
\hline No & 1 & 25 & \\
\hline \multicolumn{4}{|l|}{$\begin{array}{l}\text { Circumciser knows the impacts } \\
\text { of circumcision during delivery? }\end{array}$} \\
\hline Yes & 3 & 75 & \\
\hline No & 1 & 25 & \\
\hline \multicolumn{4}{|l|}{$\begin{array}{l}\text { Circumciser is trained on FGM } \\
\text { program }\end{array}$} \\
\hline Yes & 1 & 25 & \\
\hline No & 3 & 75 & \\
\hline \multicolumn{4}{|l|}{$\begin{array}{l}\text { Inclination of circumciser on } \\
\text { FGM continuity }\end{array}$} \\
\hline Yes & 2 & 50 & \\
\hline No & 2 & 50 & \\
\hline
\end{tabular}

Table 5: Frequency distribution of circumciser respondents about FGM at Tulli and Ararso, Somali, Ethiopia.

\begin{tabular}{|l|c|c|}
\hline Variable & Frequency & Percent \\
\hline Area & & \\
\hline Tulli & 4 & 66.7 \\
\hline Ararso & 2 & 33.3 \\
\hline $\begin{array}{l}\text { Respondent says community members } \\
\text { relate FGM with religion }\end{array}$ & & \\
\hline Yes & 3 & 50 \\
\hline No & 3 & 50 \\
\hline Respondent has daughters & & \\
\hline Yes & 6 & 100 \\
\hline No & 0 & 0 \\
\hline $\begin{array}{l}\text { Circumcision status of daughters of } \\
\text { respondents }\end{array}$ & & \\
\hline Circumcised & 2 & 33.3 \\
\hline Not circumcised & 4 & 66.7 \\
\hline $\begin{array}{l}\text { Respondent had discussed with circum- } \\
\text { cisers to stop FGM }\end{array}$ & & \\
\hline Yes & 5 & 83.3 \\
\hline No & 1 & 16.7 \\
\hline $\begin{array}{l}\text { Respondent agrees that FGM should not } \\
\text { be practiced }\end{array}$ & & 16.7 \\
\hline Yes & 5 & \\
\hline No & & \\
\hline $\begin{array}{l}\text { Respondent told that he/she works with } \\
\text { Women's Association }\end{array}$ & & \\
\hline Yes & & \\
\hline No & & 16.7 \\
\hline Respondent had trained about FGM & & \\
\hline Yes & & \\
\hline No & & \\
\hline No response & & \\
\hline & & \\
\hline
\end{tabular}

Table 6: Frequency distribution of Religious leader or Elder respondents about FGM at Tulli and Ararso, Somali, Ethiopia.

Table 7 presents frequency distribution of local government respondents by knowledge, attitude, and practices on FGM at Tulli and Ararso. Accordingly, 6 local governments were interviewed and half (50\%) of them identified FGM rate being medium while $33.3 \%$ of them explained low rate of the practice in the areas. All (100\%) of the local government respondents explained a decreasing rate of FGM health complications and majority of them (83.3\%) felt comfortable on culmination of the practice. In $66.7 \%$ of the cases felt by the local governments, Sunna is the most commonly practiced type of FGM and mothers were the leading propagators (83.3\%) of the practice in the areas. In addition, the respondents explained that majority (83.3\%) of legal bodies were aware of FGM practice and they felt Women's Association (50\%) and social court (33.3) are the first and second leading responsible bodies to tackle the practice. 


\begin{tabular}{|c|c|c|}
\hline Variable & Frequency & Percent \\
\hline \multicolumn{3}{|l|}{ Area } \\
\hline Tulli & 4 & 66.7 \\
\hline Ararso & 2 & 33.3 \\
\hline \multicolumn{3}{|l|}{$\begin{array}{l}\text { Status FGM identified by respondent in the } \\
\text { localities }\end{array}$} \\
\hline High & 1 & 16.7 \\
\hline Medium & 3 & 50 \\
\hline Low & 2 & 33.3 \\
\hline \multicolumn{3}{|l|}{$\begin{array}{l}\text { FGM health complication rate identified by } \\
\text { respondent }\end{array}$} \\
\hline Increasing & 0 & 0 \\
\hline Decreasing & 6 & 100 \\
\hline \multicolumn{3}{|l|}{ Respondent agrees eradication of FGM } \\
\hline Yes & 5 & 83.3 \\
\hline No response & 1 & 16.7 \\
\hline \multicolumn{3}{|l|}{$\begin{array}{l}\text { Types of FGM practiced identified by } \\
\text { respondent }\end{array}$} \\
\hline Sunna & 4 & 66.7 \\
\hline Sunna and Pharaohnic & 2 & 33.3 \\
\hline \multicolumn{3}{|l|}{$\begin{array}{l}\text { Propagator of FGM identified by } \\
\text { respondent }\end{array}$} \\
\hline Mother & 5 & 83.3 \\
\hline No response & 1 & 16.7 \\
\hline \multicolumn{3}{|l|}{$\begin{array}{l}\text { FGM awareness status of legal bodies } \\
\text { identified by respondents }\end{array}$} \\
\hline Aware & 5 & 83.3 \\
\hline No response & 1 & 16.7 \\
\hline \multicolumn{3}{|l|}{$\begin{array}{l}\text { Responsible body to tackle FGM identified } \\
\text { by respondent }\end{array}$} \\
\hline Social court & 2 & 33.3 \\
\hline Women's Association & 3 & 50 \\
\hline Police or social court & 1 & 16.7 \\
\hline
\end{tabular}

Table 7: Frequency distribution of Local government respondents about FGM at Tulli and Ararso, Somali, Ethiopia.

\section{Result of in-depth interview of Women's Association}

In-depth interview of 5 members of Women's Association revealed that FGM was still a prominent problem in Tulli and Ararso areas in Somali region. They felt that mothers were the leading insisters of daughters for circumcision and Sunna was the widely used type of circumcision. They were knowledgeable on health and economic consequences of the harmful practice and highly impressed on the culmination of the practice through convincing education and discussions at different segments of the society.

\section{Discussion}

Basic indicators of FGM

Under the current study, information has been gathered on six indicators that include:-information coverage, source of information, knowledge, attitude, intention, and behavior. The above indicators are generated for FGM to serve as bench mark in future comparison and to make a comparison of the regional information with the areas.

Interview of men and women revealed that $53.7 \%$ of females were circumcised at Tulli and Ararso Somali areas. Though most agreed not to circumcise their non-circumcised daughters, Sunna or Pharaohnic circumcision type was still in practice. Culture of ancestors and religious requirements for virginity protection were the vital reasons of the practice and mothers were top in insisting on the need of FGM in the areas. Additionally, some of men and women were knowledgeable on the health consequences of circumcision and majority were in agreement to marry their son from a girl who was not circumcised. This implies that greater effort is needed to make men and women knowledgeable, skillful and shaped behaviorally to eradicate this harmful practice in the areas. Interview of youth club also showed that $40 \%$ of the circumcision practices were continued and culture of ancestors and protection of virginity were still the two common reasons for circumcision practices in the locality. Additionally, most youths were knowledgeable about the health consequences resulted after FGM and some of them felt culmination of FGM practices in the areas. Similarly, majority of circumcisers were knowledgeable on ill-health impacts of circumcision, but they all were happy with the practice and half of them were not willing to stop FGM. However, all victims interviewed felt on health impacts of circumcision while most of the victims $(80 \%)$ did not get skill training or income generating activities. Similar to the victims, all the boys interviewed felt that their sisters should not be circumcised and they all were not interested to marry a girl who was circumcised. Therefore, convincing discussions and focused training need to be given to youths, victims, boys and circumcisers to eradicate the FGM practice in the areas since knowledge, attitude and behaviors of the individuals with regard to FGM are still mixed.

Moreover, all of religious leaders interviewed felt that 50\% of community members relate FGM as religious requirement and majority of them explained that they had discussed with circumcisers and Women's Association to work together to eradicate FGM. Accordingly, half of local governments interviewed rated FGM practice medium which is decreasing in the localities and majority of them felt comfortable on culmination of the practice. Similar to responses of men and women as well as youths interviewed, Sunna is the most commonly practiced type of FGM and mothers were the leading propagators of the practice in the areas. 


\section{Critical issues to address}

- Though there is encouraging performance observed in the two areas on FGM, there is still a gap to be addressed as identified by the informants' interview. These include;

- $\quad$ FGM is still prevalent and performed in the area. Both the quantitative and qualitative information have confirmed the issue.

- Religious leaders, local governments and women's association have not yet reached to an agreement on the total eradication of FGM.

- Some support Sunna or Pharaohnic type of circumcision while others support total eradication.

The involvement of the youths and boys is not well addressed as some are voluntary to marry a girl who is not circumcised while others still insist girls to be circumcised. The ideas of these boys must be challenged This concept of the boys must be totally avoided by organizing the boy's group separately and conducting different panel discussion to reach to an agreement that all boys should be educated on the harm caused by the practice so that they may volunarrily decide. voluntary to marry a girl who is not circumcised. As the youth are the future husband or wife, mother and father of children they play a significant role in the eradication of FGM.

\section{Future intervention strategies}

Considering the continuity of the actors on the areas of FGM, all the respondents have suggested the following points for future intervention that includes:

- More identification of victims that need medical support. Then provide them with skill training and IGA program. Encourage victims to teach the community members and share their experiences for others. It will be good to identify victims who faced problem due to Sunna or Pharaohnic circumcisions and show the public even the two type of circumcisions can seriously affect the health (physical, social and sexual functions) of women in the community

- Mediations through panel discussions in different target groups to reach a common agreement on the circumcision issues

- Identify and try to have an inventory of circumcisers;

- Convince all of them by intensive intervention by showing films that include the Sunna or Pharaohnic type of circumcision impacts on health conditions of women.

- Provide them with alternative jobs by creating IGA.

- Train them on how they assist during delivery and transform them to trained traditional birth attendants (TBA).

- Then pay them a good salary like a midwifery nurse to serve as change agent and to advise mothers not expose their female children for any form of FGM after they assist delivery.
- Organize both in and out of school youth clubs. Assist this youth clubs to perform different panel discussion among the youth to reach to a common agreement on the issue of FGM as husband or wife, future mother and father.

- Identify all religious leaders and local governments in the areas and organize a discussion among them to reach to a common agreement to teach the communities why they should not perform even the Sunna or Pharaohnic type of circumcision.

- Invite religious scholars and exemplary government bodies from other places who can clearly explain for them during their discussion

- Produce Information Education and Communication (IEC) materials like leaflets, posters, bill boards and films that show the harmful effects of FGM in general and the Sunna or Pharaohnic type of circumcision, in particular.

- Capacity building and creating a system to lay the ground for sustainability of the program is also suggested by all target group included in both the qualitative and quantitative approach.

\section{Conclusion and Recommendation \\ Conclusion}

From this mixed quantitative and qualitative study, information coverage on FGM at Tulli and Ararso was incomplete in different segments of the community members. The quantitative information has also been supported by the different targets who were asked under the qualitative approach. Because, all the target groups including the beneficiaries work on the issue to fulfill critical gaps observed, there is improved knowledge on FGM for attitudinal and behavioral change. Moreover, the respondents have also suggested the future intervention strategies to fill the current critical gaps these are mentioned again in the discussion section that needs a particular attention by all actors in the area. They have witnessed as there is improved knowledge on FGM for attitudinal and behavioral change. However, all the target groups including the beneficiaries or the public explained a further work on the issue to full fill critical gaps observed and discussed. The respondents have also suggested future intervention strategies to fill the current critical gaps and these are mentioned again in the discussion section that needs a particular attention by all actors in the area.

\section{Recommendation}

The different targets included under the current assessment have witnessed a lot of activities performed in the areas with regard to FGM. However, they have also impressed that a lot remain to be performed for significant reduction or total eradication of FGM in the two areas. In relation to this and according to the suggested points by the current study respondents, the following points are recommended by men and women, youth clubs, victims, boys, circumcisers, religious leaders, local governments and 
women's. Encourage victims to teach the community membranes and share their experiences for other and also providing the skill training and income generations program. Moreover, arranging mediations of panel discussions in different target groups to reach a common agreement on the circumcision issues and suggesting a clear intervention policy and strategies to tackle circumcision problem association.

\section{Ethics Approval and Consent to Participate}

The study was reviewed and approved by the Mother and Child Development Organization MCDO Review committee. Ethical approval was obtained from Somali Regional State Health Bureau Research Ethics Committee.

\section{Author's Contributions}

RWA conducted the statistical analysis, wrote the paper, and designed the study and manuscript drafting. EG and GE participated in data collection, statistical analysis and manuscript drafting. All authors read and approved the final manuscript.

\section{Consent for Publication}

Not applicable.

\section{Competing Interest}

The authors declare that they have no competing interests.

\section{Funding}

This study obtained fund from Mother and Child development organization only. The authors declare that they have not received funds for the publication of this manuscript. The authors also declare that they have had no external source of grant/fund for both data collection and publication.

\section{Acknowledgements}

This study was funded by Mother and Child Development Organization. We are very grateful to Mr. Dumessa Idessa for editing this article. Finally, I would like to thank all respondents and data collectors for their cooperation for their unreserved cooperation.

\section{Bibliography}

1. Assefa D., et al. Harmful Traditional Practices (2005).

2. Fikrie Z. "Factors associated with perceived continuation of females' genital mutilation among women in Ethiopia”. Ethiopian Journal of Health Sciences 20.1 (2010).

3. Oloo H., et al. "Female Genital Mutilation practices in Kenya: The role of Alternative rites of passage: A case study of Kisii and Kuria districts". FGM-report (2011).

4. Ismail EA. Female Genital Mutilation Survey In Somaliland. Report (2009).

5. Population Reference Bureau. Female Genital Mutilation/Cutting: Data and Trends (2010).
6. Unicef. Eradication of female genital mutilation in Somalia.

7. Jeppsson A., et al. "Health care providers' perceptions on harmful traditional health practices in Ethiopia”. The Ethiopian Journal of Health Development 17.1 (2003): 35-44.

8. MCDO. Evaluation of MCDO Project at Keberbeya and Awabere Refugee Camps in Somali Region (2010).

\section{Assets from publication with us}

- Prompt Acknowledgement after receiving the article

- Thorough Double blinded peer review

- Rapid Publication

- Issue of Publication Certificate

- High visibility of your Published work

Website: https://www.actascientific.com/

Submit Article: https://www.actascientific.com/submission.php Email us: editor@actascientific.com

Contact us: +919182824667 